\title{
Волоконный световод со смещённой сердщевиной для подавления ВРМБ
}

\author{
М.М. Худяков ${ }^{1,2, *}$, В.В. Алексеев ${ }^{1}$, Д.С. Липатов ${ }^{3}$, А.Н. Гурьянов ${ }^{3}$, \\ В. Темянко ${ }^{4}$, М.М. Бубнов ${ }^{1}$, М.Е. Лихачёв ${ }^{1}$ \\ ${ }^{1}$ Институт общей физики им. А.М. Прохорова РАН, \\ Научный центр волоконной оптики им. Е.М. Дианова \\ ${ }^{2}$ Московский физико-технический институт \\ ${ }^{3}$ Институт химии высокочистых веществ РАН \\ ${ }^{4}$ College of Optical Sciences, University of Arizona \\ *E-mail: DAngeL.74@gmail.com
}

DOI: 10.31868/RFL2020.160-161

Вынужденное рассеяние Мандельштама-Бриллюэна (ВРМБ) - нелинейный эффект с наименьшим порогом в оптических волоконных световодах (ВС) для излучения с узкой спектральной шириной (<100 МГц). Наиболее сильно это проявляется для ВС большой длины и с маленьким диаметром сердцевины, таких как высоко-нелинейные ВС, используемые в усилителях, основанных на эффекте вынужденного комбинационного рассеяния.

Порог ВРМБ обратно пропорционален ширине спектра усиления ВРМБ. Существует ряд способов уширения спектра ВРМБ в ВС: модификация акустического профиля (распределения скорости звука) [1], [2]; создание градиента температуры [3], натяжения [4] или концентрации легирующей добавки в сердцевине [5] по длине. Первый метод позволяет получить подавление ВРМБ на 6,4 дБ для пассивного ВС [1] и 11,2 дБ для активного [2] по сравнению со стандартными $\mathrm{BC}$ с аналогичными оптическими параметрами. Однако, этот метод требует точного контроля концентраций легирующих добавок для достижения высокого подавления, что делает создание таких ВС технологически сложным и дорогим. Второй метод позволяет сдвинуть частоту пика ВРМБ по длине ВС, что приводит к эффективному уширению спектра. Использование градиента температуры позволило повысить порог ВРМБ на 4,8 дБ [3], натяжения - 15,3 дБ [4]. Большая разница между результатами объясняется тем, что максимальный градиент температуры ВС в [3] ограничен $140{ }^{\circ} \mathrm{C}$, что приводит к максимальному сдвигу спектра ВРМБ на 180 МГц, в то время как в [4] максимальный сдвиг составил 1,7 ГГц для натяжения $30 \mathrm{H}$, ограниченного прочностью ВС. Использование данных методов в практических условиях является сложной инженерной задачей по причине необходимости создания однородного градиента для достижения максимального результата. Более того долговременная надёжность ВС в условиях высокой температуры или сильного растяжения сильно сокращается.

В данной работе мы предлагаем и демонстрируем новый метод подавления ВРМБ в ВС путём смещения его сердцевины к краю оболочки с последующим наматывание его на катушку маленького диаметра. Это позволяет создать периодический градиент натяжения в сердцевине ВС без сложной системы используемой в [4]. Более того, сердцевина ВС в данной работе претерпевает как растяжение, так и сжатие, что позволяет практически удвоить максимальный градиент натяжения (смотри Рис. 1а)).

Заготовка BC была произведена методом MCVD. Сердцевина была легирована 24 мол.\% $\mathrm{GeO}_{2}$, что соответствует $\Delta \mathrm{n}=0.0035$. Заготовка была обработана для получения сердцевины с диаметром 8 мкм, смещённой от оболочки диаметром 125 мкм на 9 мкм (смотри Рис. 1б)). Рассчитанный диаметр поля моды на длине волны 1550 нм составил 6,7 мкм, длина волны отсечки второй моды соста- 
вила 1750 нм. Для улучшения прочности и долговременной надёжности ВС помимо полимерного покрытия непосредственно на световод наносилось так же герметичное углеродное покрытие [6]. Это позволило намотать ВС на катушку с внешним диаметром 28 мм без риска обрывов световода на протяжении его срока службы.
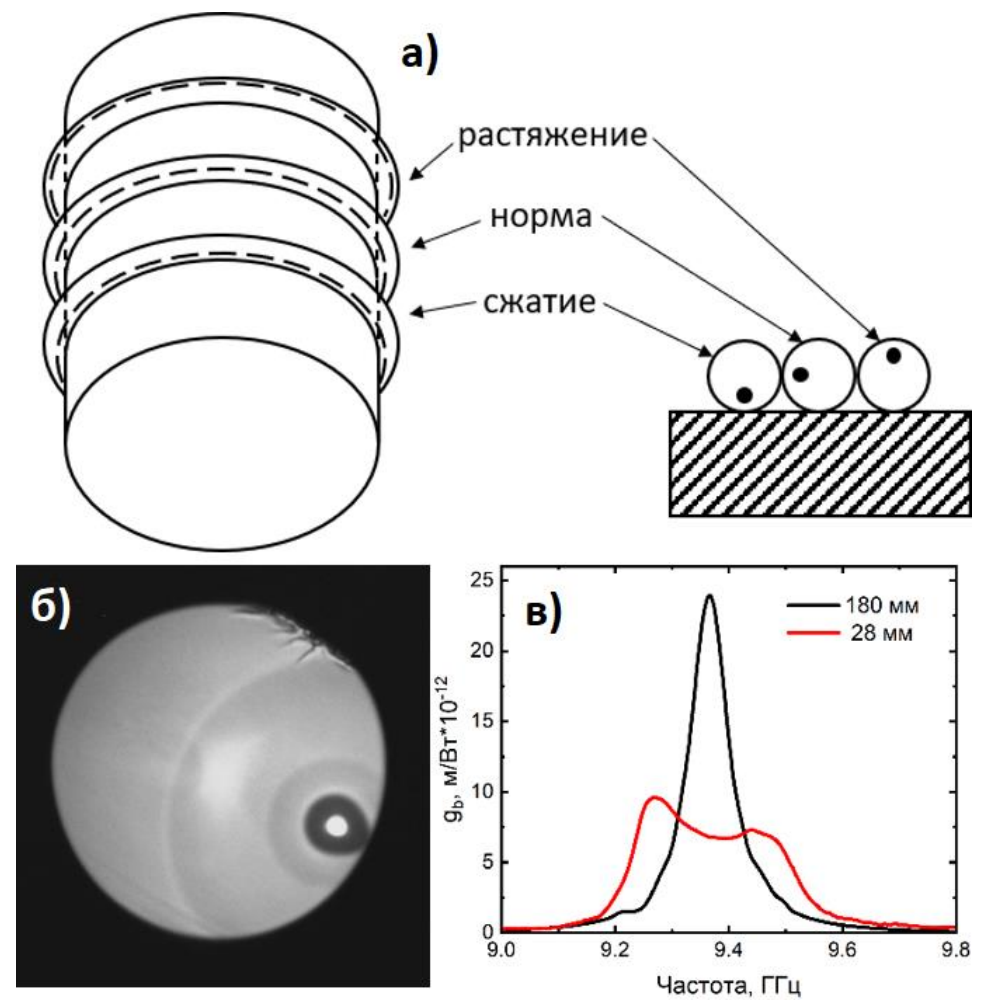

Рис. 1. а) Схема намотки ВС со смещённой сердцевиной; б) фотография торца ВС; в) измеренные спектры ВРМБ при намотке на катушки разного диаметра.

Измерение спектра ВРМБ производилось методом запуска пробного излучения с отстроенной длиной волны навстречу фиксированному сигналу [7]. Результаты приведены на рисунке 1в). Ширина на полувысоте спектра ВРМБ ненапряжённого ВС, намотанного на катушку диаметром 180 мм, составила 78 МГц. При намотке ВС на катушку диаметром 28 мм ширина увеличилась до 272 МГц. При этом пиковое значение коэффициента усиления уменьшилось с 24 пм/Вт до 9,3 пм/Вт, что демонстрирует подавление ВРМБ на 4,1 дБ. Стоит отметить, что при намотке ВС на катушку с более маленьким диаметром или при создании ВС с большим диаметром оболочки (и большим смещением сердцевины от центра) подавление ВРМБ окажется выше.

Исследование выполнено при финансовой поддержке РФФИ в рамках научного проекта № 19-38-90281.

\section{Литература}

[1] M. M. Khudyakov, M. E. Likhachev, et al., in Fiber Lasers XIV: Technology and Systems (2017), 10083, 1008313.

[2] M. D. Mermelstein, M. J. Andrejco, et al., 6873, 68730N (2008).

[3] J. Hansryd, F. Dross, et al., J. Light. Technol. 19, 1691-1697 (2001).

[4] R. Engelbrecht, M. Mueller, et al., in 2009 IEEE/LEOS Winter Topicals Meeting Series (IEEE, 2009), 248-249.

[5] J. Nagel, V. Temyanko, et al., in 2013 IEEE Photonics Conference (IEEE, 2013), 2, 271-272.

[6] V. A. Bogatyrjov, M. M. Bubnov, et al., Opt. Eng. 30, 690 (1991).

[7] M. M. Khudyakov, M. E. Likhachev, et al., Quantum Electron. 46, 468-472 (2016). 